\title{
Pengaruh Inflasi, Nilai Tukar Dan Indeks Harga Saham Gabungan (IHSG) terhadap Kupon Obligasi Negara Ritel (ORI)
}

\author{
Rizka Maulida | Nendi Juhandi | Budi Permana Yusuf
}

How to cite : Maulida, R., Juhandi, N.,\& Yusuf, B., P.,(2020). Pengaruh Inflasi, Nilai Tukar Dan Indeks Harga Saham Gabungan (IHSG) terhadap Kupon Obligasi Negara Ritel (ORI). 1(1). Jurnal Jurnal Manajemen Bisnis dan Publik(JMBP). 48-54.

Opened Access Article

\# Published Online on 12 November 2020

Submit your paper to this journal 
Recieved: 09 Oktober 2020

Accepted: 2 November 2020

Published: 12 November 2020

*Corresponding author: Rizki Maulida, Universitas Muhammadiyah Prof Dr Hamka, Indonesia

E-mail:

rizkimaulida.mn@gmail.com

Reviewing editor:

Bambang Dwi Hartono, Universitas Muhammadiyah Prof. DR. HAMKA- Jakarta.

Additional information is available at the end of the article

\section{Pengaruh Inflasi, Nilai Tukar Dan Indeks Harga Saham Gabungan (IHSG) terhadap Kupon Obligasi Negara Ritel (ORI)}

\author{
Rizki Maulida*1, Nendi Juhandi², Budi Permana Yusuf ${ }^{3}$
}

Abstract. Penelitian ini bertujuan untuk mengungkapkan pengaruh langsung inflasi, nilai tukar dan Indeks Harga Saham Gabungan (IHSG) terhadap kupon Obligasi Negara Ritel (ORI) dan pengaruh tidak langsung inflasi dan nilai tukar terhadap kupon ORI. Metode yang digunakan adalah metode kuantitatif dengan data sekunder yang diperoleh dari website resmi Kementerian Keuangan Republik Indonesia, Badan Pusat Statistik (BPS), Bank Indonesia dan Bursa Efek Indonesia (BEI). Populasi pada penelitian ini berjumlah ORI seri 001 sampai dengan 016 dan seluruh populasi dijadikan sampel. Data yang diperoleh diolah menggunakan analisis deskriptif kuantitatif dan menggunakan analisis jalur untuk menjawab hipotesis penelitian. Hasil Penelitian menunjukkan bahwa engaruh langsung inflasi (X1) terhadap IHSG (X3) adalah sebesar $-0,466$ dimana signifikansi adalah sebesar 0,007 yang berarti berpengaruh negatif,dan signifikan; pengaruh langsung nilai tukar (X2) terhadap IHSG (X3) adalah sebesar 0,603 dengan signifikansi 0,001 yang berarti berpengaruh positif dan signifikan.; pengaruh langsung inflasi $(\mathrm{X} 1)$ terhadap kupon $\mathrm{ORI}(\mathrm{Y})$ adalah 0 dengan signifikasi 1 yang berarti tidak berpengaruh, sedangkan pengaruh tidak langsung adalah 0,518; pengaruh langsung nilai tukar (X2) terhadap kupon ORI (Y) adalah sebesar 0,440 dengan signifikasi 0,104.

Key words: Inflasi, Nilai Tukar, IHSG, Kupon ORI.

\section{TENTANG PENULIS}

Rizki Maulida adalah mahasiswa pascasarjana UHAMKA yang lulus pada tahun 2020. la saat ini sedang aktif dalam penelitian-penelitian yang terkait dengan branding suatu produk dalam memasuki pasar nasional dan internasional.

Nendi Juhandi adalah Dosen Sekolah Pascasarjana Universitas Muhammadiyah Prof. DR. HAMKA pada program studi Magister Manajemen. la saat ini sedang aktif dalam berbagai penelitian terkait dengan manajemen dan bisnis pada kebijakan publik.

Budi Pernama Yusuf adalah Dosen Sekolah Pascasarjana Universitas Muhammadiyah Prof. DR. HAMKA pada program studi Magister Manajemen. la saat ini sedang aktif dalam berbagai penelitian terkait dengan manajemen dan bisnis pada kebijakan publik

\section{PENELITIAN SEBELUMNYA}

Penelitian sebelumnya membahas kajian manajemen terkait pemasaran produk-produk dengan memperkuat branding. Fokus pada kepemimpinan sumber daya manusia dalam meningkatan produktifitas. Saat ini peneliti membahas Pengaruh Inflasi, Nilai Tukar Dan Indeks Harga Saham Gabungan (IHSG) terhadap Kupon Obligasi Negara Ritel (ORI). (c) 2020 The Author(s). This open access article is distributed under a Creative Commons Attribution (CC-BY) 4.0 license. 


\section{Pendahuluan}

Investasi adalah kegiatan penempatan dana yang dimiliki dalam periode tertentu dengan mengharapkan manfaat atau keuntungan yang lebih di masa yang akan datang. Investasi telah dilakukan masyarakat Indonesia secara luas, baik investasi dalam bentuk aset real seperti tanah dan properti maupun aset finansial seperti tabungan, deposito, reksadana, saham dan instrumen pasar modal lainnya. Proses investasi perlu dipahami dengan baik agar tercapainya tujuan investasi yaitu pengurangan dampak inflasi, penghematan pajak dan peningkatan taraf hidup, baik proses investasi, mulai dari konsep dasar, pemahaman pola hubungan antara hasil (return) dan risiko suatu investasi sampai keputusan dibuat. Pilihan berinvestasi instrumen keuangan di pasar modal adalah alternatif bagi investor yang memiliki modal terbatas. Instrumen keuangan yang diperjualbelikan di pasar modal antara lain saham, surat utang (obligasi), waran, right, reksadana, dan berbagai instrumen derivatif seperti option, futures, dan lain-lain.

Obligasi merupakan alternatif investasi yang aman karena memberikan kupon bunga dan jangka waktu yang telah ditentukan di awal (Wijayanto, 2015). Obligasi pemerintah merupakan instrumen yang paling aman dibandingkan dengan obligasi korporasi, karena pembayaran pokok dan bunganya dijamin $100 \%$ oleh pemerintah. Keuntungan yang dapat diraih investor dengan pembelian ORI antara lain mendapatkan capital gain dan bunga serta terhindar dari kemungkinan gagal bayar (default). Potensi capital gain yang diperoleh dari trading lebih besar terjadi pada obligasi pemerintah karena pergerakan lebih fluktuatif, namun untuk timing trading perlu menganalisa kondisi makro. Faktor makro antara lain inflasi,nilai tukar, Indeks Harga Saham Gabungan (IHSG), tingkat suku bunga bank dan jumlah uang beredar (Bareksa, 2016).

Penelitian terdahulu yang relevan, membahas tentang pengaruh makroekonomi seperti inflasi, nilai tukar terhadap obligasi pemerintah di Indonesia. Hasil penelitian terdahulu menunjukan bahwa faktor makroekonomi mempengaruhi sukuk dan obligasi (Suriani et al, 2018), meskipun tidak semua faktor makroekonomi memberikan pengaruh positif terhadap obligasi pemerintah. Seperti dalam penelitian Kurniasih dan Restika (2015) bahwa nilai tukar dan kepemilikan asing berpengaruh negatif terhadap yield obligasi pemerintah.

Sejak pertama kali diterbitkan pada tahun 2006, pemerintah telah menerbitkan 16 seri ORI. ORI seri pertama sampai seri keenambelas, memiliki jangka waktu berkisar dari 3 - 5 tahun, dengan kupon yang ditawarkan fluktuatif berkisar 5,85\% - 12,05\%. Sesuai dengan salah satu tujuan investasi, yaitu untuk mendapat keuntungan di masa yang akan datang, maka investor perlu mengetahui kapan waktu yang tepat untuk melakukan investasi. terdapat berbagai permasalahan yang memungkinkan berpengaruh terhadap kupon ORI yaitu inflasi, nilai tukar, IHSG, BI Rate, dan tingkat bunga deposito. Beberapa batasan masalah dalam penelitian ini adalah informasi seputar ORI (kupon), inflasi, nilai tukar dan Indeks Harga Saham Gabungan (IHSG) pada masa penawaran ORI. Perumusan masalah penelitian adalah apakah ada pengaruh langsung inflasi dan nilai tukar terhadap IHSG maupun inflasi, nilai tukar dan IHSG terhadap kupon ORI secara langsung dan pengaruh tidak langsung inflasi dan nilai tukar terhadap kupon ORI.

Hipotesis penelitian adalah terdapat menganalisis pengaruh langsung inflasi dan nilai tukar terhadap IHSG maupun inflasi, nilai tukar dan IHSG terhadap kupon ORI secara langsung dan pengaruh tidak langsung inflasi dan nilai tukar terhadap kupon ORI.

Tujuan penelitian ini adalah menganalisis pengaruh langsung inflasi dan nilai tukar terhadap IHSG maupun inflasi, nilai tukar dan IHSG terhadap kupon ORI secara langsung dan pengaruh tidak langsung inflasi dan nilai tukar terhadap kupon ORI. 


\section{Material Dan Metode}

Penelitian ini bersifat kuantitatif, dengan teknik dokumentasi berupa data kupon ORI yang ditawarkan melalui website Kementerian Keuangan Republik Indonesia www.kemenkeu.go.id, inflasi merupakan inflasi tahunan (year on year) yang datanya diperoleh melalui website Badan Pusat Statistik www.bps.go.id, nilai tukar merupakan nilai tengah Rupiah terhadap USD yang datanya diperoleh dari website Bank Indonesia www.bi.go.id dan IHSG yang diperoleh di laman website resmi Bursa Efek Indonesia (BEI) www.idx.co.id dan yahoo finance.

Variabel bebas dalam penelitian ini yaitu inflasi $\left(X_{1}\right)$, nilai tukar $\left(X_{2}\right)$ dan IHSG $\left(X_{3}\right)$ sebagai variabel intervening. Untuk variabel terikat adalah Kupon ORI $(\mathrm{Y})$. Pendekatan yang akan dilakukan dalam penelitian ini adalah pendekatan analisis kuantitatif berdasarkan informasi statistika. Software yang digunakan untuk mendukung penelitian ini adalah program SPSS (Statistical Product and Service Solutions) versi 25.

Populasi penelitian ini adalah ORI001 sampai dengan ORI016 yang telah dikeluarkan pemerintah dalam kurun waktu 2006 - 2019. Teknik sampling yang digunakan adalah sampling jenuh. Sampel penelitian ini adalah ORI001 sampai dengan ORI016 yang telah dikeluarkan pemerintah dalam kurun waktu 2006 - 2019.

Statistik uji yang digunakan sebagai berikut:

\section{a. Koefisien determinan}

Besarnya pengaruh variabel " $X_{1}$ " dan " $X_{2}$ " terhadap variabel " $Y$ " dapat diketahui dengan menggunakan analisis koefisien determinasi, yang diperoleh dengan mengkuadratkan koefisien korelasinya yang dinyatakan dalam persentase yaitu:

$$
K_{d}=r^{2} \times 100 \%
$$

Keterangan:

$\begin{array}{ll}\mathrm{Kd} & =\text { Nilai koefisien determinasi } \\ r & =\text { Nilai koefisien korelasi }\end{array}$

b. Analisis jalur

Menganalisis hubungan sebab akibat yang terjadi pada regresi berganda jika variabel bebasnya mempengaruhi variabel tergantung tidak hanya secara langsung, tetapi juga secara tidak langsung.

\section{Hasil dan Pembahasan}

Analisis jalur akan menjelaskan hasil persamaan analisis jalur untuk menghitung pengaruh inflasi, nilai tukar dan IHSG terhadap Kupon ORI. Tiap jalur yang diuji menunjukan pengaruh langsung dan tidak langsung.

\subsection{Model I}

\subsection{Model II}

Model ini akan dijelaskan pengaruh inflasi dan nilai tukar sebagai variabel independent terhadap IHSG sebagai variabel dependen. Untuk perhitungan dengan menggunakan SPSS versi 25 adalah sebagai berikut :

Tabel 1. Koefisien Jalur Pengaruh Inflasi dan Nilai Tukar Terhadap IHSG 


\section{Coefficients ${ }^{3}$}

\begin{tabular}{|c|c|c|c|c|c|}
\hline \multirow[b]{2}{*}{ Model } & \multicolumn{2}{|c|}{ Unstandardized Coefficients } & \multirow{2}{*}{$\begin{array}{c}\text { Standardized } \\
\text { Coefficients } \\
\text { Beta } \\
\end{array}$} & \multirow[t]{2}{*}{$t$} & \multirow[t]{2}{*}{ Sig. } \\
\hline & B & Std. Error & & & \\
\hline 1 (Constant) & -100.595 & 1599.082 & & -0.063 & 0.951 \\
\hline Inflasi & -278.389 & 87.233 & -0.466 & -3.191 & 0.007 \\
\hline Nilai Tukar & 0.497 & 0.120 & 0.603 & 4.131 & 0.001 \\
\hline
\end{tabular}

Sumber : data diolah

Tabel 2. R Square Jalur Pengaruh Inflasi dan Nilai Tukar Terhadap IHSG

\section{Model Summary}

\begin{tabular}{llrrr}
\hline Model & R & R Square & Adjusted R Square & Std. Error of the Estimate \\
\hline 1 & $.864^{a}$ & 0.747 & 0.708 & 919.27426 \\
\hline
\end{tabular}

\section{Model}

Model ini akan dijelaskan pengaruh inflasi, nilai tukar dan IHSG sebagai variabel independent terhadap Kupon ORI sebagai variabel dependen. Untuk perhitungan dengan menggunakan SPSS versi 25 adalah sebagai berikut :

Tabel 3. Koefisien Jalur Pengaruh Inflasi, Nilai Tukar dan IHSG Terhadap Kupon ORI

\section{Coefficients ${ }^{\mathrm{a}}$}

\begin{tabular}{|c|c|c|c|c|c|c|}
\hline \multirow[b]{2}{*}{ Model } & & \multicolumn{2}{|c|}{ Unstandardized Coefficients } & \multirow{2}{*}{$\begin{array}{c}\text { Standardized } \\
\text { Coefficients } \\
\text { Beta }\end{array}$} & \multirow[b]{2}{*}{$\mathrm{t}$} & \multirow[b]{2}{*}{ Sig. } \\
\hline & & $\mathrm{B}$ & Std. Error & & & \\
\hline \multirow[t]{4}{*}{1} & (Constant) & 8.762 & 1.832 & & 4.783 & .000 \\
\hline & Inflasi & $-5.113 E-5$ & .133 & .000 & .000 & 1.000 \\
\hline & Nilai Tukar & .000 & .000 & .440 & 1.762 & .104 \\
\hline & IHSG & -.001 & .000 & -1.112 & -3.565 & .004 \\
\hline
\end{tabular}

a. Dependent Variable: Kupon ORI

Sumber : data diolah

Tabel 4. R Square Jalur Pengaruh Inflasi, Nilai Tukar dan IHSG Terhadap Kupon ORI

\begin{tabular}{ll|r|r|c} 
& \multicolumn{2}{c}{ Model Summary } & \multicolumn{1}{c}{$\begin{array}{c}\text { Std. Error of the } \\
\text { Estimate }\end{array}$} \\
\hline Model & $\mathrm{R}$ & R Square & Adjusted R Square & \multicolumn{1}{c}{ Ester } \\
\hline 1 & $.840^{\mathrm{a}}$ & .705 & .631 & $1.05303 \%$ \\
\hline
\end{tabular}

a. Predictors: (Constant), IHSG, Inflasi, Nilai Tukar

Sumber : data diolah 
Hasil dari uji t pengaruh langsung inflasi terhadap Kupon ORI, diperoleh angka signifikansi lebih dari 0,05 yaitu sebesar 1,000 . Hal tersebut menunjukkan bahwa inflasi tidak berpengaruh langsung terhadap terhadap Kupon ORI. Besarnya nilai koefisien jalur menunjukkan angka 0,000. Sesuai dengan hasil penelitian yang dilakukan oleh Sukanto (2009), bahwa inflasi tidak berpengaruh signifikan terhadap harga obligasi pemerintah Indonesia. Hasil penelitian yang dilakukan oleh Widajati (2009), nilai $t$-value lebih dari 0,05 adalah inflasi sehingga dapat dikatakan bahwa inflasi tidak mempunyai hubungan dan pengaruh terhadap harga obligasi. Tingkat inflasi tidak mempengaruhi tingkat bunga, jadi secara tidak langsung inflasi tidak mempengaruhi harga obligasi Negara Ritel yang dikeluarkan pemerintah. Sehingga dapat dikatakan meskipun inflasi mempunyai kecenderungan naik tetapi pemerintah berusaha meyakinkan pelaku pasar bahwa kondisi ekonomi Indonesia masih cukup baik sehingga tidak ada alasan fundamental bagi pasar untuk membuat pergerakan negatif.

Pengaruh tidak langsungnya sebesar $P X_{3}, X_{1}=-0,466$ dikalikan $P Y, X_{3}=-1,112$ sama dengan $=$ 0,518 bernilai positif. Menurut (Saputra dan Prasetiono, 2014), perubahan laju inflasi yang sangat fluktuatif akan berdampak pada investasi surat-surat berharga karena dengan meningkatnya inflasi berarti berinvestasi pada surat-surat berharga seperti obligasi dirasa makin berisiko karena kondisi pasar sedang mengalami kenaikan harga secara keseluruhan, sehingga dengan tingginya risiko yang diakibatkan oleh laju inflasi, investor mengharapkan imbal hasil (yield) yang lebih tinggi atas investasinya, dengan kata lain laju inflasi mempengaruhi besar kecilnya yield obligasi yang diinginkan oleh investor.

Hasil dari uji t pengaruh langsung nilai tukar terhadap Kupon ORI, diperoleh angka signifikansi lebih dari 0,05 yaitu sebesar 0,104 . Hal tersebut menunjukkan bahwa nilai tukar tidak berpengaruh langsung terhadap terhadap Kupon ORI. Besarnya nilai koefisien jalur menunjukkan angka 0,440. Hal serupa disimpulkan penelitian Ichsan, dkk (2013) bahwa nilai tukar rupiah yang tidak memengaruhi nilai obligasi pemerintah. Jika nilai Rupiah terhadap Dolar AS melemah, pemerintah melalui Bank Indonesia akan melakukan kebijakan moneter, salah satunya menarik jumlah rupiah yang beredar di pasaran, dengan mekanisme menjual obligasi (bond) kepada masyarakat, menaikkan suku bunga tabungan (saving rate) agar masyarakat gemar atau tertarik menyimpan uangnya di bank.

Pengaruh tidak langsungnya nilai tukar terhadap kupon ORI melalui IHSG sebagai variabel intervening adalah sebesar $\mathrm{PX}_{3}, \mathrm{X}_{2}=0,603$ dikalikan $\mathrm{PY}, \mathrm{X}_{3}=-1,112$ sama dengan $=-0,671$, bernilai negatif. Menurut Dewi, dkk. (2016) Dolar Amerika sering digunakan sebagai pilihan dalam berinvestasi oleh investor, karena nilai tukar dolar Amerika relatif stabil dan merupakan mata uang yang paling banyak beredar di masyarakat dibandingkan dengan mata uang lainnya. Nilai tukar dolar Amerika yang menguat terhadap rupiah mengindikasikan bahwa pasar valuta asing lebih menarik daripada pasar modal, sehingga investor akan beralih pada pasar valuta asing.

Hasil dari uji t diperoleh angka signifikansi kurang dari 0,05 yaitu sebesar 0,004. Hal tersebut menunjukkan bahwa inflasi berpengaruh signifikan terhadap IHSG. Besarnya nilai koefisien jalur menunjukkan angka -1,112, IHSG berpengaruh negatif terhadap Kupon ORI. Menurut Andriansyah (2010), dalam jangka panjang kedua pasar tersebut akan bergerak bersamaan (interdependent atau cointegrted) dengan arah pergerakan yang berlawanan karena jika pada satu pasar dapat diperoleh imbal hasil diatas normal maka dana dari yang lain akan mengalir ke pasar tersebut sehingga akan terjadi peningkatan harga di pasar pertama dan penurunan harga di pasar kedua. Pernyataan tersebut menjelaskan bahwa yang dimaksud kedua pasar tersebut adalah pasar saham dan pasar obligasi. Hubungan antara pasar saham dan obligasi seharusnya bernilai negatif. Saat pasar saham menurun, investor akan beralih kepada obligasi yang memiliki bunga lebih besar, karena sejatinya tujuan utama investasi adalah mendapatkan keuntungan. 


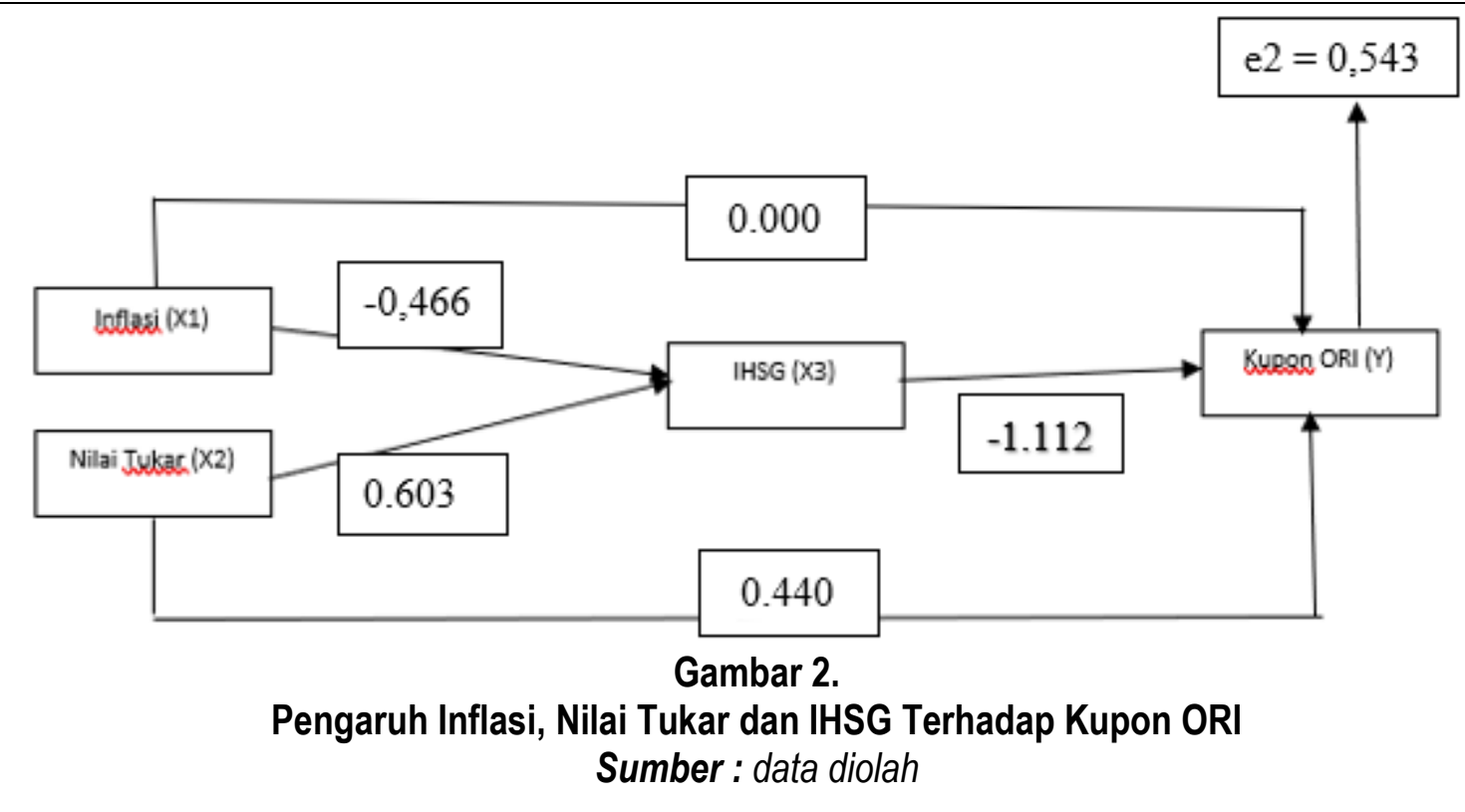

\section{Kesimpulan}

Adapun kesimpulan dari hasil penelitian yang telah dilakukan dan pembahasan yang telah dijelaskan pada bab sebelumnya adalah sebagai berikut :

a. Inflasi berpengaruh negatif dan signifikan terhadap IHSG, dengan nilai analisis jalur sebesar $-0,466$.

b. Nilai Tukar berpengaruh positif dan signifikan terhadap IHSG, dengan nilai analisis jalur sebesar 0,603.

c. Inflasi tidak berpengaruh terhadap Kupon ORI secara langsung (dengan nilai analisis jalur sebesar 0,000) maupun secara tidak langsung (dengan nilai analisis jalur sebesar 0,518).

d. Nilai tukar tidak berpengaruh terhadap Kupon ORI secara langsung (dengan nilai analisis jalur sebesar 0,440 ) namun secara tidak langsung berpengaruh negatif (dengan nilai analisis jalur sebesar $-0,671)$.

e. IHSG berpengaruh negatif dan signifikan terhadap Kupon ORI, dengan nilai analisis jalur sebesar $-1,112$.

\section{Referensi}

Andriansyah. (2010). Hubungan Dinamis antara Pasar Saham dan Pasar Obligasi Pemerintah di Pasar Modal Indonesia. Warta Bapepam.

Astuti, R., Lapian, J., \& Rate, P. V. (2016). Pengaruh Faktor Makro Ekonomi.

Badan Pusat Statistik. (2019). Inflasi. Retrieved from https://www.bps.go.id/subject/3/inflasi.html.

Bank Indonesia. (2009). Laporan Tahunan, Laporan Perekonomian Indonesia Tahun 2008. Retrieved from https://www.bi.go.id/id/publikasi/laporantahunan/perekonomian/Pages/lpi_2008.aspx. 
Bareksa. (2016). Obligasi Pemerintah Vs Obligasi Korporasi, Pilih Yang Mana?. Retrieved from https://www.bareksa.com/id/text/2016/04/22/obligasi-pemerintah-vs-obligasi-korporasi-pilih-yangmana/13174/news.

Dewi, N., Purbawangsa, I., \& Abundanti, N. (2016). Pengaruh Suku Bunga, Nilai Tukar, Coupon Rate, dan Likuiditas Obligasi Terhadap Harga Pasar Obligasi Pada Sektor Keuangan. E-Jurnal Manajemen Unud, Vol. 5, No. 5.

Ichsan, Syamni, G., \& Nurlela. (2013). Dampak BI Rate, Tingkat Suku Bunga, Nilai Tukar, dan Inflasi Terhadap Nilai Obligasi Pemerintah. Jurnal Keuangan dan Perbankan, Vol.17, No.2 , 310-322.

Kementerian Keuangan RI. (2019). Obligasi Negara Ritel. Retrieved from https://www.kemenkeu.go.id/media/13505/frequently-asked-question-ori_okt-2019-vf-2.pdf .

Kurniasih, A., \& Restika, Y. (2015). The influence of Macroeconomic Indicators and Foreign Ownership on Government Bond Yields: A Case of Indonesia. Mediterranean Journal of Social Sciences, 20392117.

Saputra, T., \& Prasetiono. (2014). Analisis Faktor-Faktor yang Mempengaruhi Yield Obligasi Konvensional di Indonesia (Studi Kasus Pada Perusahaan Listed di BEI). Jurnal Studi Manajemen \& Organisasi 11 (2014), 67-77.

Sukamto, \& Wahyuni, S. (2018). Pengaruh Inflasi, Suku Bunga dan Nilai Tukar Rupiah Terhadap Indeks Harga Saham Gabungan (IHSG) di Bursa Efek Indonesia (BEI). E-Journal UMM, Vol.6 No.2.

Sukanto, E. (2009). Pengaruh Suku Bunga Deposito, Kurs Rupiah-USD, Tingkat Inflasi, IHSG dan Volume Transaksi Terhadap Harga Obligasi Pemerintah RI (SUN). Fokus Ekonomi. Vol. 4 No. 2 , 9-23.

Suriani, Majid, M., Masbar, R., \& A.W, N. (2018). Macroeconomic Determinants of the Capital Market in Indonesia: A Comparative Analysis between Sukuk and Bonds Markets. Human Resource Management Academic Research Society. Vol.7 No. 2, 1-17.

Widajati, A. (2009). Inflasi dan Tingkat Bunga Terhadap Harga Obligasi Negara Ritel yang Diterbitkan Pemerintah. Jurnal Keuangan dan Perbankan, Vol. 13, 97-105.

Wijayanti, A. (2013). Pengaruh Beberapa Variabel Makro Ekonomi dan Indeks Pasar Modal Dunia Terhadap Pergerakan IHSG di Bursa Efek Indonesia. Jurnal IImiah Fakultas Ekonomi dan Bisnis.

Wijayanto, S. (2015). Strategi Jitu Investasi Obligasi Korporasi. Jakarta: PT. Elex Media Komutindo. 